\title{
How Does the Concept of Resilient City Work in Practice? Planning and Achievements
}

\author{
Chuan Wang *(D), Xinhua Li and Siheng Li \\ School of Architecture, Southeast University, 2 Sipailou, Nanjing 210096, China; xinhua_li@seu.edu.cn (X.L.); \\ sihengli@seu.edu.cn (S.L.) \\ * Correspondence: chuanwang@seu.edu.cn
}

\begin{abstract}
In the past decade, resilient cities (RCs) have gained extensive attention in academic and political debates as a vision of urban futures. In particular, with the support of the Rockefeller Foundation's Resilient City 100 Program (RC100), a number of cities worldwide have pushed this concept forward from theory to practice through their RC plans/strategies. However, there is widespread doubt regarding how much this holistic idea of the future built environment contributes to urban practice. After developing a scoring evaluation matrix based on the synthesis of existing RC assessment frameworks, this review scrutinizes the plans, reports, city leaders' speeches, official websites and academic reviews of five representative resilient cities and investigates their motivations, planning and achievements. The results demonstrate a huge theoretical and practical gap in RC: while RC plans attempt to expand as comprehensively as possible from cities' initially narrow motivations, their achievements in implementation are limited. Although RC provides more holistic solutions to the cities, the limited resources mean that cities have to prioritize their urgent issues in their everyday practice. This paper calls for designating more feasible and specific features in RC visions and maintaining regular alignments from planning to actions in future RC practice.
\end{abstract}

Citation: Wang, C.; Li, X.; Li, S. How Does the Concept of Resilient City Work in Practice? Planning and Achievements. Land 2021, 10, 1319. https://doi.org/10.3390/ land10121319

Academic Editors: Elizelle Juanee Cilliers and Sarel Cilliers

Received: 5 November 2021

Accepted: 27 November 2021

Published: 1 December 2021

Publisher's Note: MDPI stays neutral with regard to jurisdictional claims in published maps and institutional affiliations.

Keywords: resilient city; theory and practice; planning practice; future built environment; scoring evaluation matrix; assessment framework; urban resilience; RC100

\section{Introduction}

With the increasing proportion of cities in human settlements, the giant and complex system of cities has encountered increasing uncertainties and risks [1,2]. In the past two decades, terrorist attacks, extreme weather, financial crises, global warming and other crises have significantly impacted our vision of the future built environment. In the face of various natural and human disasters, the vulnerability of cities has become a major problem impeding sustainable urban development [3]. Resilient city (RC), a fashionable concept in urban planning, emerged as an attempt to resolve this problem. Scholars aim to use this concept to improve the resistance, recovery and adaptability of complex urban systems and to enhance the predictability and guidance for urban planning [3-6]. Furthermore, after years of advocacy and debates, cities have gradually adopted and translated RC into their master plans, strategic plans and community plans [7-9]. In particular, with the support of the Rockefeller Foundation's Resilient City 100 Program (RC100) since 2013, a large number of cities worldwide have pushed this concept forward from theory to practice through their RC plans/strategies [10-13].

However, while many city authorities increasingly use the RC concept in envisioning the future built environment, some scholars have questioned how much content of RC can be implemented in reality and are concerned about the gap between its theory and practice [14-17]. In contrast to the heated theoretical discussions, RC practice still has not demonstrated convincing models. Some scholars have warned that RC may become another fuzzy concept such as "sustainable development" in the hands of policymakers who change RC policy standards flexibly according to different situations [18-20]. Empirical 
data also demonstrate that the same plan or urban policies can be interpreted selectively in the implementation stage by different government agencies $[9,20]$. In essence, RC, as a systematic concept for future cities, can only have a positive impact on the built environment if its multiple and integrated dimensions are considered. The limited achievements mean that the initial comprehensive RC plans may not perform as well in reality as expected in the planning.

Therefore, this research aims to explore the gap between the planning and implementation of RC through an analysis of the empirical data of five representative RC cities. Although some individual RC cases have been critically reviewed and assessed [9,12,21-25], the uniqueness of each city means that a systematic and comparative review of RC planning and implementation is still needed. To fill this gap, this research compares the RC planning and implementation of five cities using a newly synthesized scoring matrix evaluation framework and detailed narratives of each city's RC trajectory. This research attempts to answer how the RC concept lands in urban practice on a global scale.

In the next sections, this paper first reviews the development of resilience in the academic circles, particularly on its trajectory associated with cities. This is the theoretical foundation for understanding the changes and mismatches of RC in theory and practice. Second, five representative $R C$ cities are selected as the resources of the empirical data. They are analyzed through a comprehensive scoring evaluation matrix of 26 indicators in seven clusters developed based on the grounded analysis of existing assessment frameworks. The scored results are accompanied by the narratives of each case to demonstrate the differences among the motivations, planning and achievements of representative $R C$ cities. This reveals that, although authorities usually make their RC plans inclusive and comprehensive, the implementation is limited to easy or urgent parts. Through an in-depth analysis of the relationship among motivations, planning and achievement, this study demonstrates the contribution and constraints of RC for urban practice and suggests future development directions.

\section{Expanding Dimensions of the Resilient City}

The concept of resilience first appeared in ecological scholarship in 1973, when C. S. Holling used the term "resilience" to describe the ability of ecological systems to resist and/or adapt to a particular disturbance and recover its normal functioning or state of balance, which may set the initial baseline or a new situation [26]. This concept challenged the then-dominant stable equilibrium theory in ecology, with an emphasis on non-linear dynamics and uncertainty. It later extended to social systems to describe the interaction between disturbance and reorganization in social-ecological synergies [27,28].

The concept of resilience was then introduced to the built environment, focusing on the relationship between ecological systems in the city [29] and cities' responses to natural disasters $[3,6]$. The development of social resilience has motivated urban scholars to regard cities as giant social-ecological systems, emphasizing integrated feedback of urban systems and cross-scale dynamic interaction of urban elements [30]. RC research began to focus on how the urban system achieves a new balance through the utilization, preservation, release and reorganization of social cycles [31]. Along with public awareness shifting to financial austerity, class conflicts and populist movements after the 2008 financial crisis, more scholars have begun associating the RC concept with sociology, political science and economics to seek new urban solutions related to social equality, political empowerment and economic optimization $[13,32,33]$. Resilience's connotation with dynamics, co-evolution and elasticity makes this concept an ideal concept for dealing with unpredictable changes in the future built environment. Considering the increasing corpulent content of RC, some scholars have attempted to organize them into coherent frameworks [4,5,34]. For instance, Desouza and Flanery proposed a resilient urban evolution mechanism based on a complex adaptive system by simplifying the model of the interactive relationship between the urban system and the agent as the two-element attributes of "materiality" and "sociality" [4]. However, these attempts have not prevented the continuous expansion of the RC theory, particularly after 
the involvement of the wheeling-out power of NGOs, including the United Nations Office for Disaster Risk Reduction, the World Bank and the Rockefeller's Foundation [35,36]. A recent review shows that the scope of RC is still continuously shifting and expanding in academic discourse [37], tending to cover increasingly important aspects of the economy, infrastructure, society and ecology for the future built environment.

\section{Materials and Methods}

\subsection{Case Selection and Data Resources}

This research selects five cities as empirical data to analyze the gap between the planning and implementation of RC, according to cities' planning activities, data accessibility and regional representativeness. First, each selected city has either specific RC plans or at least a substantial part influenced by the RC concept in the city's master or strategic plans. As the concept of "resilience" is becoming increasingly popular in urban planning and management, many city plans contain "resilient" content. For this research, at least a designated section is needed to be regarded as a planning action for RC. Although almost all RC100 cities contain a comprehensive RC plan as required in their RC100 participation, this selection attempts to extend beyond the RC100 inventory to represent a more diverse scope. Therefore, every selected city has at least one RC plan other than its RC100 plan.

Second, sufficient data can be retrieved to assess representative cities' RC implementation. This part is more critical for this selection procedure, as implementation data are usually more fragmented than planning documents. Four types of resources were retrieved and synthesized for this assessment: cities' official websites on their RC actions and achievements, recent academic reviews on specific cities' RC practice, city leaders' recent speeches or interviews on RC and cities' own review reports. News reports are generally excluded in this assessment, as our preliminary study discovered that their links with resilience heavily depend on journalists' own interpretations. Admittedly, languages are a constraint in this selection process, but the authors have tried their best to obtain access to all available data with the help of Google Translate's website translation service. The assessed documents span from 2010 to September 2021, with a focus on the past three years.

As a result, the selected cities are London, Addis Ababa, Rotterdam, New York and Surat (Table 1). This selection covers cities in different continents (Europe, North America, Asia and Africa) and different developing stages (developed and developing countries). It should be noted that only (at least regionally) large cities were selected because of the scarcity of open data of smaller cities for this analysis.

Table 1. Representative RC Cities and Their Practice Data Resources.

\begin{tabular}{|c|c|c|}
\hline City & Planning Documents & Implementation Data $^{1}$ \\
\hline London & $\begin{array}{l}\text { London Resilience Partnership Strategy } 2020 \\
\text { London City Resilience Strategy } 2020 \text { (RC 100) }\end{array}$ & $\begin{array}{l}\text { City Official Website: https:/ / www.london.gov.uk/ } \\
\text { Academic Reviews: [8,38] } \\
\text { City Leaders' Speech: Deputy Mayor for Environment \& } \\
\text { Energy Shirley Rodrigues's Speech to Resilience First, } 13 \\
\text { January } 2021 \text { [39] }\end{array}$ \\
\hline Addis Ababa & $\begin{array}{l}\text { Addis Ababa, Enhancing Urban Resilience } \\
2015 \\
\text { Addis Ababa Resilience Strategy } 2020 \text { (RC 100) }\end{array}$ & $\begin{array}{l}\text { City Official Website: https: / / resilientaddis.org/ } \\
\text { Academic Reviews: [40-47] } \\
\text { City Leaders' Interview: An interview with Chief Resilience } \\
\text { Officer [48] }\end{array}$ \\
\hline Rotterdam & $\begin{array}{l}\text { Rotterdam Climate Change Adaptation } 2013 \\
\text { Rotterdam Resilience Strategy } 2016 \text { (RC 100) }\end{array}$ & $\begin{array}{l}\text { City Official Website: https://www.resilientrotterdam.nl; } \\
\text { https:/ / www.rotterdam.nl } \\
\text { Academic Reviews: }[9,12,24,49]\end{array}$ \\
\hline
\end{tabular}


Table 1. Cont.

\begin{tabular}{rll}
\hline \multicolumn{1}{c}{ City } & \multicolumn{1}{c}{ Planning Documents } & \multicolumn{1}{c}{ Implementation Data $^{\mathbf{1}}$} \\
\hline \multirow{5}{*}{ New York } & $\begin{array}{l}\text { One NYC-A Stronger, more resilient New } \\
\text { York 2013 } \\
\text { One NYC-The Plan for a Strong and Just City } \\
2015 \text { (RC 100) }\end{array}$ & $\begin{array}{l}\text { City Official Website: https://www1.nyc.gov; } \\
\text { https://nyc-oem.maps.arcgis.com/ } \\
\text { Academic Reviews: [25,50] }\end{array}$ \\
& $\begin{array}{l}\text { Surat City Resilience Strategy 2011 } \\
\text { Surat }\end{array}$ & $\begin{array}{l}\text { City Official Website: https://www.suratmunicipal.gov.in/ } \\
\text { Academic Reviews: [51-53] } \\
\text { Governmental Reviews: [54] }\end{array}$ \\
\hline
\end{tabular}

${ }^{1}$ The accessing details of city official websites are available in Supplement S1.

\subsection{Assessment Framework}

To analyze the gap between the planning and implementation of RC, this research establishes an assessment framework based on the comparison and synthesis of existing assessment methods. Although relevant to and inspiring for the RC concept, current assessment frameworks on similar concepts, such as "Goal 11 (sustainable cities and communities) of the Sustainable Development Goals" [55] and "Disaster Resilience Scorecard for Cities" [56], have different priorities and coverage for cities. Therefore, this research principally focuses on the current assessment methods directly named after "resilient city" or "city/urban resilience" to avoid further expansion of this research target.

Existing RC assessment frameworks primarily focus on two interactive directions: process and content. The process framework focuses on the different stages of urban resilience and usually uses flow maps to demonstrate the relationships between different components $[4,5,29,34]$. This direction typically closely represents the nature of the $\mathrm{RC}^{\prime} \mathrm{s}$ complexity, diversification, dynamic decision-making and uncertainty. However, its complexity and ambiguity make it difficult to measure the empirical data. Second, contentbased frameworks include different ideas that can be associated with the enhancement of urban resilience. This direction is usually summarized in an indexed evaluation system that attempts to quantify each indicator that represents an idea. Through the standardization and weighting of the index data, the results of the superimposed index data are used as the standard for evaluating urban resilience [57]. However, it is difficult to reach a consensus on how to determine the weights of indicators within a complex system. In particular, different cities encounter different environmental challenges, which hinders unified standardization and weighting to adapt to different environments. Instead of standardization within predetermined structures, this research uses a grounded approach to build an RC assessment framework based on the synthesis of existing content-based assessment frameworks $[58,59]$. This enables this research to assemble a comprehensive framework to cover as many aspects of RC-related contents as possible.

The analyzed resources cover the most cited literature on RC assessment in academic databases (Web of Science, Scopus and Google Scholar) as well as the widely applied assessment methods in city plans. It should be noted that two types of assessment literature were excluded from this synthesis but used as supplementary references. The first type includes assessment frameworks that focus only on specific aspects of RC, e.g., community disaster mitigation [60] and the relationship between ecology and planning [29]. The second is the frameworks' scope that is too broad to assess the RC practice. Acknowledging that many indicators (e.g., GDP per capita, employment rate and crime rate) can be linked to RC assessment, this research contends that it is still difficult to determine their exact contribution to RC practice. As a result, this research selects and compares five representative assessment frameworks $[3,5,61-63]$ and lists their contents pertaining to $R C$ in detail (Table A1).

After combining similar ideas, a 26-indicator table is created as the evaluation matrix to assess different aspects of the planning and implementation of RC (Table 2). Furthermore, a grounding method [64] is used to categorize the indicators into seven sections: public participation, social service, robust economics, hazard management, institutional 
optimization, physical/engineering and natural enhancement. Instead of dividing RC into equally balanced aspects (e.g., social-physical [4] or economic, environmental, security, social and political [63]), this categorization aims to provide groups of ideas pertaining to $\mathrm{RC}$ for easier understanding in the later analysis. Therefore, clustering is loosely gathered depending on the closeness and commonality of the listed indicators. The matrix of indicators represents a broad but assessable scope of RC for envisioning the future built environment. This summary lays the foundation for the analysis of selected RC cases.

Table 2. RC Assessment Framework.

\begin{tabular}{|c|c|}
\hline Clusters & Indicators \\
\hline Public Participation (PP) & $\begin{array}{l}\text { 1. Educate developers and the public about hazard } \\
\text { mitigation } \\
\text { 2. Encourage community involvement and citizen } \\
\text { participation } \\
\text { 3. Collective learning process from past urban hazards }\end{array}$ \\
\hline Social Service (SS) & $\begin{array}{l}\text { 4. Enforce security and laws to reduce crimes } \\
\text { 5. Set ensured human security for providing basic living } \\
\text { needs } \\
\text { 6. Assist vulnerable neighborhoods and populations } \\
\text { (increase social equity) } \\
\text { 7. Enhance robust public health systems and emergency } \\
\text { medical care }\end{array}$ \\
\hline
\end{tabular}

8. Diversify livelihoods that can mitigate business

$\begin{array}{ll}\text { Robust Economics (RE) } & \text { 9. Adopt sustainable economic initiatives }\end{array}$

10. Use/facilitate alternative energy (e.g., solar and wind to reduce greenhouse gas emission)

11. Identify, monitor and assess hazards and vulnerability

12. Land use and planning management for natural

Hazard Management (HM) hazard-prone areas

13. Enhance building hazard resistance by appropriate construction regulations

14. Build effective emergency response services/initiatives

15. Increase capacity of governmental institutions through wide collaboration

Institutional Optimization (IO) 16. Adopt a flexible planning system and adaptive design process

17. Employ agile city management for uncertainty and challenges

18. Effective coordination with other government bodies

19. Set robust protective infrastructure with regular maintenance

20. Build/optimize a distributed or decentralized hazard

Physical/Engineering (PE) mitigation system

21. Build/enhance reliable ICT infrastructure (communication network)

22. Use/optimize a sustainable urban form

23. Optimize diverse, effective, affordable, sustainable transport

24. Conserve, manage and protect ecosystems

Natural Enhancement (NE) 25. Optimize urban blue-green ecological networks within compact cities

26. Maintain diversity in biological systems

This assessment framework uses a scoring system to measure each indicator in later analysis: 3 indicates that this point is well elaborated in planning or largely put into city 
actions; 2 indicates that this idea is partially included in planning proposals or practiced to some extent; 1 indicates that only a limited part of this point is mentioned in the planning stage or very little is realized in terms of implementation; 0 denotes that this point is not mentioned or achieved at all. Compared with its existing counterparts, this assessment framework not only has a wider coverage of most aspects that cities have planned and practiced pertaining to $\mathrm{RC}$ but also demonstrates a relatively feasible approach to measure each indicator in the framework.

\subsection{Comparison and Narratives of Empirical Data}

For the analysis of each city, this research focuses on the comparison of three aspects: motivations, planning and achievements. First, early-stage documents are traced to reveal the initial motivations for adopting the RC concept or participating in the RC100. This part aims to answer why this city started to use the concept of resilience in its city planning and management, particularly before the formal names of the plans included the term resilience. Second, this research uses the assessment framework to determine the content coverage of two selected RC plans for each city (the planning documents column in Table 1). This section aims to discover what is envisioned in cities' plans when the RC concept is introduced as well as their priorities in these strategies compared with earlier motivations. Thirdly, achievements are summarized in the same framework using synthesized information resources. Admittedly, it is difficult to check every detail of the city's achievements. The synthesis of multiple data (the achievement data column in Table 1) can at least identify the key areas that selected cities have achieved under the RC concept. To make the cross-city data comparable, this research set the same standard for assessing achievement data for each city: only the ideas that have been translated into projects, policies, funds or programs with real actions and named after or described as "resilient" are accounted as the achievements. Besides, implementation actions before the RC plans can still be regarded as achievements if they are officially associated with the RC concepts.

It should be noted that this scoring criteria principally focuses on the scope that the $\mathrm{RC}$ practice has covered but cannot quantify to what extent one specific idea has been realized. Some large gaps in the degree of implementation are discussed as narratives of each city's RC journey to additionally support conclusions. Furthermore, this research briefly compares the narratives of each city from initial motivations to implementation and highlights some controversial indicators.

\section{Results}

This research employs the scoring evaluation matrix developed in Section 3.2 to assess every indicator in the most representative RC plan, RC 100 plan and planning achievements of each city. The detailed scoring basis is available in Supplement $\mathrm{S} 1$ for each number. This resulting matrix (Table 3) provides comparable and computable data between planning and achievements, as well as among different cities, as the foundation to analyze RC planning and achievements. 
Table 3. Scoring results of representative cities' RC planning and achievements.

\begin{tabular}{|c|c|c|c|c|c|c|c|c|c|c|c|c|c|c|c|c|c|c|c|}
\hline & & & & London & & & $\begin{array}{l}\text { Addis } \\
\text { Ababa }\end{array}$ & & & Rotterdam & & & New York & & & Surat & & & \\
\hline 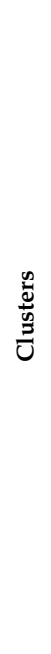 & $\dot{z}$ & 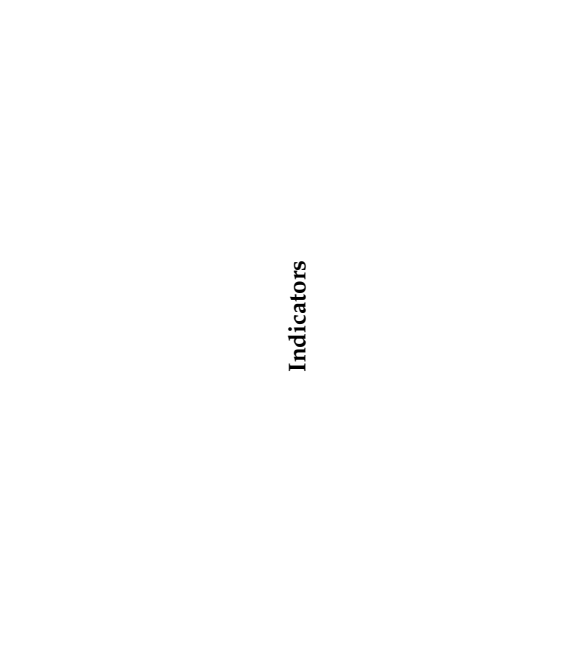 & 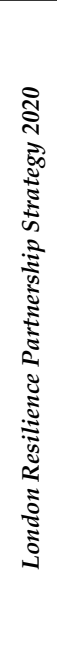 & 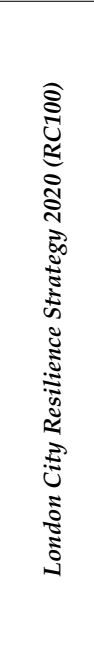 & 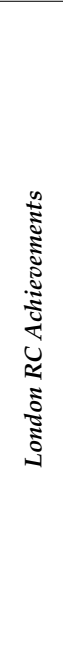 & 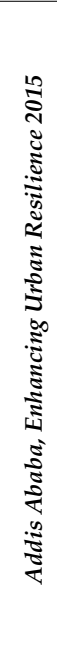 & 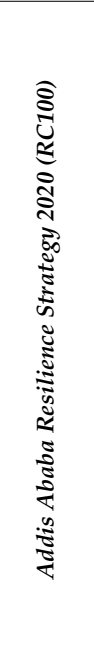 & 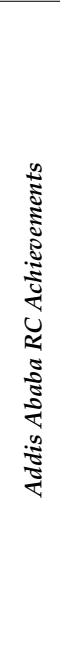 & 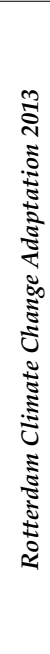 & 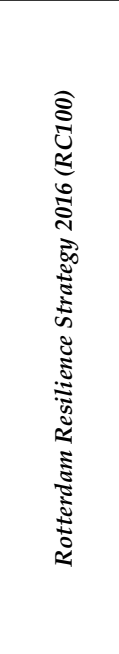 & 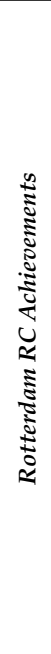 & 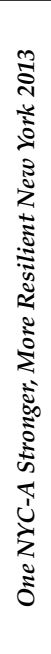 & 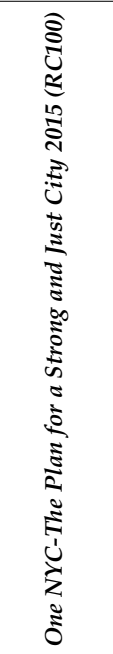 & 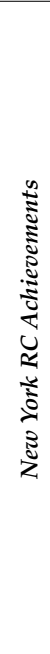 & 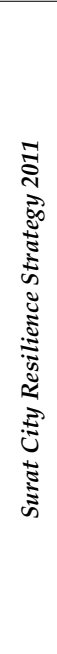 & 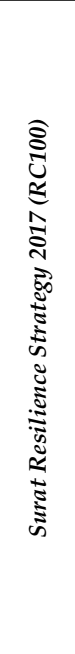 & 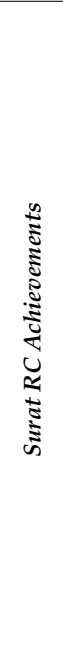 & 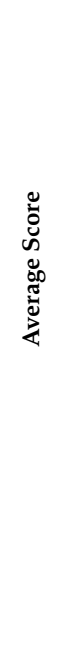 & 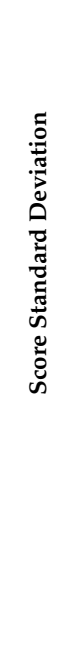 \\
\hline \multirow[t]{2}{*}{ PP } & 2 & $\begin{array}{l}\text { Encourage community involvement and citizen } \\
\text { participation }\end{array}$ & 3 & 3 & 2 & 2 & 3 & 1 & 3 & 3 & 3 & 3 & 3 & 2 & 1 & 2 & 2 & 2.40 & 0.71 \\
\hline & 3 & Learn collectively from past urban hazards & 1 & 0 & 2 & 2 & 1 & 2 & 2 & 0 & 0 & 0 & 0 & 0 & 3 & 3 & 1 & 1.13 & 1.09 \\
\hline \multirow{4}{*}{ SS } & 4 & Enforce security and laws to reduce crimes & 0 & 1 & 1 & 1 & 0 & 1 & 0 & 3 & 0 & 0 & 0 & 0 & 0 & 1 & 2 & 0.67 & 0.87 \\
\hline & 5 & $\begin{array}{l}\text { Set ensured human security for providing basic } \\
\text { living needs }\end{array}$ & 0 & 1 & 1 & 2 & 3 & 1 & 0 & 0 & 0 & 1 & 2 & 0 & 1 & 2 & 0 & 0.93 & 0.93 \\
\hline & 6 & $\begin{array}{l}\text { Assist vulnerable neighborhoods and populations } \\
\text { (increase social equity) }\end{array}$ & 0 & 1 & 0 & 0 & 1 & 0 & 1 & 0 & 1 & 2 & 2 & 1 & 1 & 2 & 0 & 0.80 & 0.75 \\
\hline & 7 & $\begin{array}{l}\text { Enhance robust public health systems and } \\
\text { emergency medical care }\end{array}$ & 0 & 0 & 0 & 1 & 3 & 2 & 1 & 2 & 0 & 3 & 1 & 0 & 2 & 2 & 2 & 1.27 & 1.06 \\
\hline \multirow{3}{*}{ RE } & 8 & $\begin{array}{l}\text { Diversify livelihoods that can mitigate business } \\
\text { interruption impacts }\end{array}$ & 0 & 2 & 2 & 0 & 2 & 1 & 0 & 2 & 1 & 1 & 2 & 2 & 0 & 2 & 0 & 1.13 & 0.88 \\
\hline & 9 & Adopt sustainable economic initiatives & 0 & 0 & 3 & 2 & 3 & 2 & 3 & 3 & 0 & 1 & 0 & 0 & 0 & 0 & 2 & 1.27 & 1.29 \\
\hline & 10 & $\begin{array}{l}\text { Use/facilitate alternative energy (solar, wind, etc. to } \\
\text { reduce greenhouse gas emission) }\end{array}$ & 0 & 1 & 1 & 3 & 3 & 2 & 0 & 3 & 3 & 1 & 0 & 0 & 3 & 2 & 0 & 1.47 & 1.26 \\
\hline
\end{tabular}


Table 3. Cont.

\begin{tabular}{|c|c|c|c|c|c|c|c|c|c|c|c|c|c|c|c|c|c|c|c|}
\hline \multirow[b]{2}{*}{ 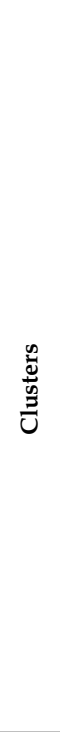 } & \multirow[b]{2}{*}{$\dot{\mathbf{z}}$} & \multirow[b]{2}{*}{ 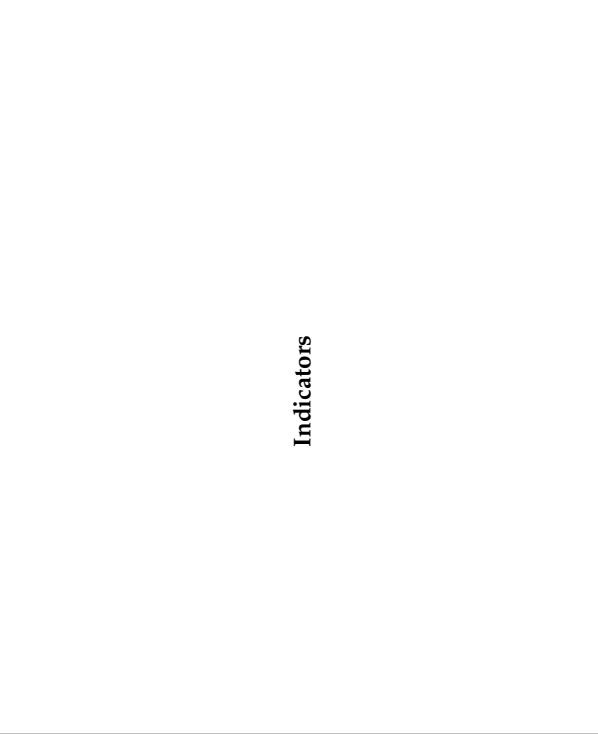 } & \multicolumn{3}{|c|}{ London } & \multicolumn{3}{|c|}{$\begin{array}{l}\text { Addis } \\
\text { Ababa }\end{array}$} & \multicolumn{3}{|c|}{ Rotterdam } & \multicolumn{3}{|c|}{ New York } & \multicolumn{3}{|c|}{ Surat } & \multirow[b]{2}{*}{ 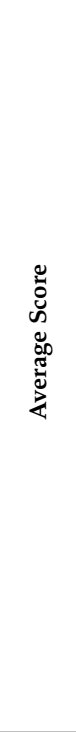 } & \multirow[b]{2}{*}{ 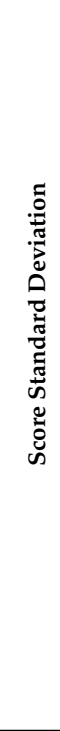 } \\
\hline & & & 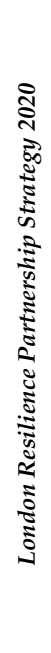 & 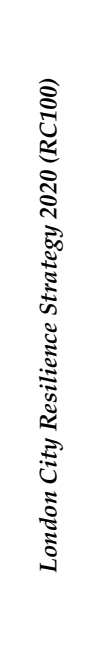 & 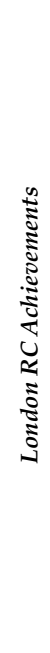 & 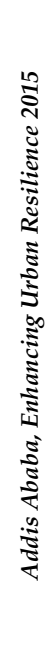 & 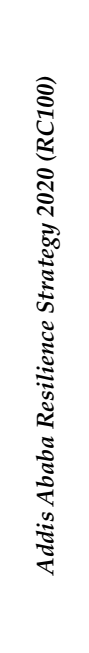 & 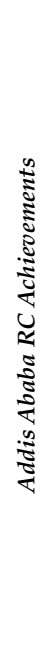 & 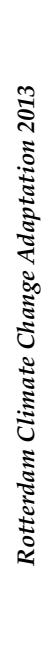 & 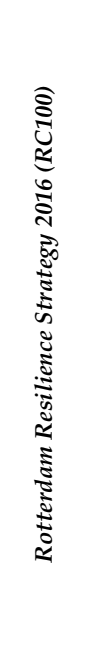 & 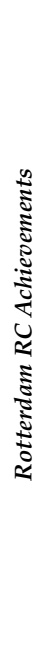 & 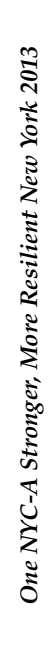 & 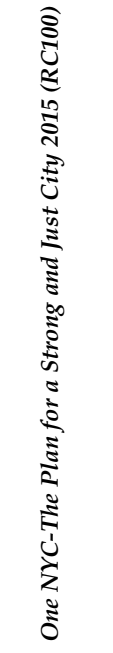 & 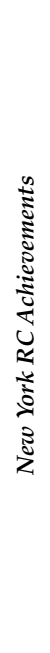 & 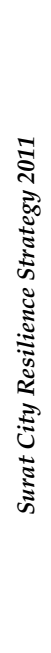 & 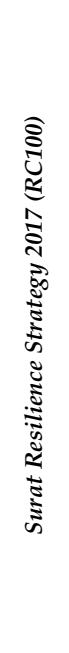 & 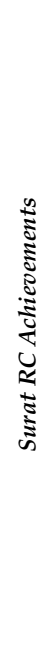 & & \\
\hline \multirow{3}{*}{$\mathrm{HM}$} & 12 & $\begin{array}{l}\text { Build effective emergency response } \\
\text { services/initiatives }\end{array}$ & 3 & 1 & 3 & 3 & 3 & 2 & 1 & 1 & 0 & 3 & 1 & 2 & 0 & 0 & 2 & 1.67 & 1.14 \\
\hline & 13 & $\begin{array}{l}\text { Enhance building hazard resistance by appropriate } \\
\text { construction regulations }\end{array}$ & 1 & 3 & 2 & 1 & 3 & 0 & 3 & 2 & 2 & 3 & 3 & 3 & 1 & 2 & 0 & 1.93 & 1.06 \\
\hline & 14 & $\begin{array}{l}\text { Land use and planning management for natural } \\
\text { hazard prone areas }\end{array}$ & 0 & 0 & 0 & 2 & 1 & 0 & 0 & 0 & 1 & 3 & 1 & 2 & 3 & 0 & 2 & 1.00 & 1.10 \\
\hline \multirow{4}{*}{ IO } & 15 & $\begin{array}{l}\text { Increase capacity of governmental institutions by } \\
\text { wide collaboration }\end{array}$ & 3 & 0 & 2 & 2 & 2 & 2 & 3 & 3 & 3 & 3 & 1 & 2 & 2 & 1 & 0 & 1.93 & 1.00 \\
\hline & 16 & $\begin{array}{l}\text { Adopt a flexible planning system and adaptive } \\
\text { design process }\end{array}$ & 0 & 3 & 1 & 1 & 1 & 0 & 2 & 1 & 0 & 2 & 1 & 0 & 0 & 0 & 0 & 0.80 & 0.91 \\
\hline & 17 & $\begin{array}{l}\text { Employ agile city management for uncertainty and } \\
\text { challenges }\end{array}$ & 2 & 3 & 0 & 1 & 1 & 1 & 3 & 2 & 1 & 0 & 0 & 1 & 0 & 0 & 0 & 1.00 & 1.03 \\
\hline & 18 & Effective coordination with other government bodies & 3 & 3 & 0 & 2 & 2 & 2 & 3 & 3 & 3 & 2 & 1 & 2 & 2 & 1 & 0 & 1.93 & 1.00 \\
\hline \multirow[b]{2}{*}{$\mathrm{PE}$} & 19 & $\begin{array}{l}\text { Set robust protective infrastructure with regular } \\
\text { maintenance }\end{array}$ & 0 & 3 & 2 & 2 & 2 & 2 & 3 & 3 & 2 & 3 & 3 & 3 & 3 & 3 & 3 & 2.47 & 0.81 \\
\hline & 20 & $\begin{array}{l}\text { Build/optimize distributed or decentralized hazard } \\
\text { mitigation system }\end{array}$ & 2 & 3 & 2 & 0 & 0 & 0 & 0 & 0 & 1 & 2 & 2 & 2 & 1 & 2 & 1 & 1.20 & 0.98 \\
\hline
\end{tabular}


Table 3. Cont.

\begin{tabular}{|c|c|c|c|c|c|c|c|c|c|c|c|c|c|c|c|c|c|c|c|}
\hline \multirow{4}{*}{ 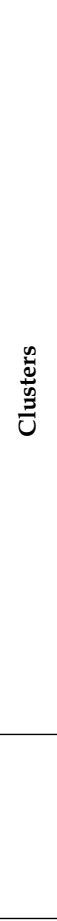 } & \multirow[b]{2}{*}{$\dot{\mathrm{z}}$} & \multirow[b]{2}{*}{ 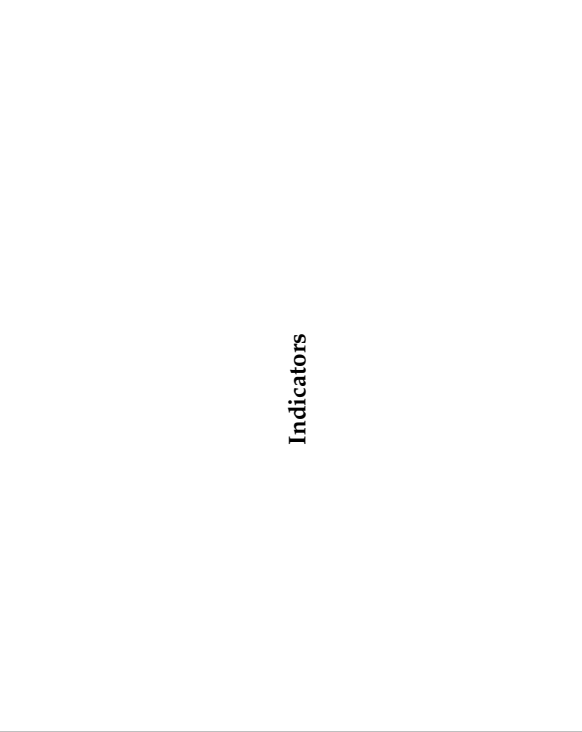 } & \multicolumn{3}{|c|}{ London } & \multicolumn{3}{|c|}{$\begin{array}{l}\text { Addis } \\
\text { Ababa }\end{array}$} & \multicolumn{3}{|c|}{ Rotterdam } & \multicolumn{3}{|c|}{ New York } & \multicolumn{3}{|c|}{ Surat } & \multirow[b]{2}{*}{ 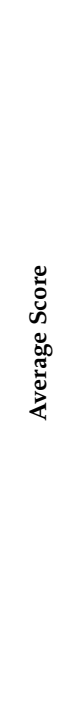 } & \multirow[b]{2}{*}{ 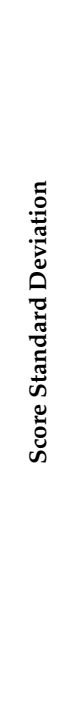 } \\
\hline & & & 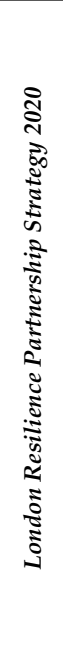 & 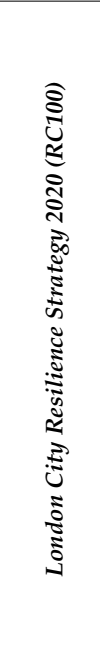 & 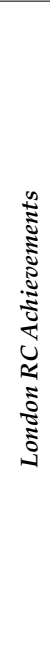 & 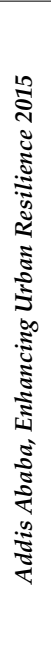 & 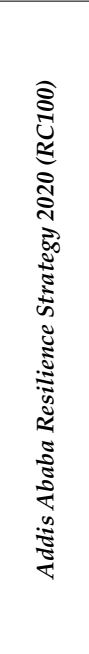 & 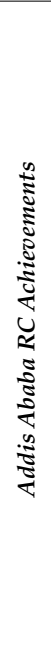 & 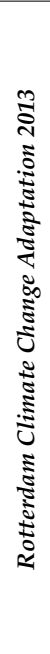 & 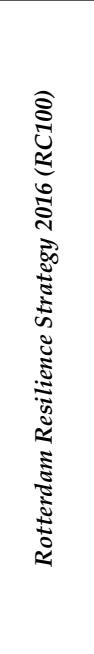 & 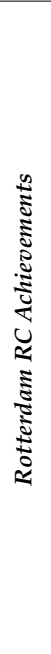 & 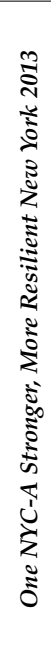 & 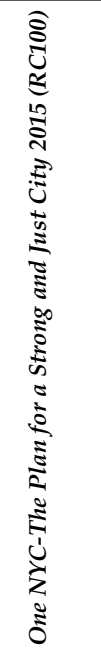 & 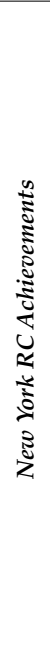 & 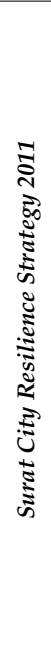 & 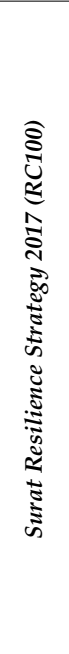 & 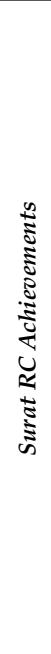 & & \\
\hline & 22 & Optimize sustainable urban form & 0 & 1 & 0 & 0 & 2 & 2 & 3 & 2 & 0 & 0 & 0 & 0 & 2 & 1 & 0 & 0.87 & 1.02 \\
\hline & 23 & $\begin{array}{l}\text { Provide diverse, effective, affordable, sustainable } \\
\text { transport }\end{array}$ & 0 & 0 & 1 & 3 & 3 & 3 & 0 & 0 & 0 & 3 & 1 & 1 & 3 & 3 & 2 & 1.53 & 1.31 \\
\hline \multirow{3}{*}{$\mathrm{NE}$} & 24 & Conserve, manage, and protect ecosystems & 0 & 0 & 0 & 1 & 3 & 2 & 0 & 3 & 1 & 2 & 0 & 1 & 0 & 3 & 1 & 1.13 & 1.15 \\
\hline & 25 & $\begin{array}{l}\text { Optimize urban blue-green ecological networks } \\
\text { within compact cities }\end{array}$ & 0 & 2 & 2 & 0 & 2 & 2 & 3 & 3 & 0 & 2 & 1 & 2 & 2 & 2 & 1 & 1.60 & 0.95 \\
\hline & 26 & Maintain diversity in biological systems & 0 & 0 & 1 & 0 & 2 & 0 & 1 & 1 & 2 & 0 & 0 & 0 & 0 & 0 & 0 & 0.47 & 0.72 \\
\hline
\end{tabular}

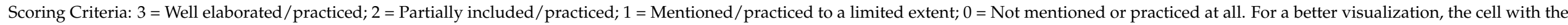
higher value is assigned with darker color. 


\subsection{Different Focuses}

The assessment results of five representative RC cities (Table 1) demonstrate that indicators are not equally treated in RC planning and implementation. Furthermore, cities also focus on what is more urgent and necessary for their urban development.

First, different indicators were weighed variously in the planning and implementation procedures. The diverse average scores of each indicator in Table 1 show that the ideas that scholars associate with the RC concept are treated drastically differently in the five cities. The high average scores and low standard deviation of some indicators in Table 3 mean some ideas have reached wide consensus in both RC planning and implementation, such as No. 2 "Encourage community involvement and citizen participation", No. 11 "Identify, monitor, and assess hazards and vulnerability" and No. 19 "Set robust protective infrastructure with regular maintenance". These ideas are widely accepted in almost every RC-related plan and are implemented widely in practice. In contrast, some widely discussed ideas are largely ignored in cities' actions. To illustrate, No. 4 "Enforce security and laws to reduce crimes" is only elaborated in Rotterdam's RC100 plan but is surprisingly not mentioned at all in its RC plan or its implementation. Furthermore, No. 16 "Adopt flexible planning system and adaptive design process" is an important approach to realize London' resilience but is almost entirely ignored elsewhere. In addition, No. 26 "Maintain diversity in biological systems" has been widely discussed in academic discourse and in the policymaking of RC $[61,65]$ but has been ignored in practice. Although some ideas have been eagerly included as part of the RC concept in academic circles, cities do not have much interest in linking them with resilience. For instance, enhancing biodiversity is a critical component in London metropolitan planning and governance policies through London plans and various urban greening guides and funds [66,67], but it is not included in any of London's RC plans at all.

Second, even regarding the same idea, five cities have different approaches toward including them as a part of their RC trajectory. Since the random allocation of the $0-1-$ 2-3 scoring numbers has a standard deviation of 1.12, the high score standard deviation numbers ( $>1.2$ in the column of standard deviation in Table 3 ) indicate that these indicators are highly polarized in urban practice. Addis Ababa and Surat elaborated No. 23. "Provide diverse, effective, affordable, sustainable transport" in their plans and take real actions in their urban development (relatively high achievement score in Table 3). In contrast, Rotterdam never associates its excellent public transportation system with the RC concept in an official tone [68]. This huge divergence between cities is also observed regarding No. 9 "Adopt sustainable economic initiatives", No 10 "Use/facilitate alternative energy (e.g., solar and wind to reduce greenhouse gas emission)" and No. 21 "Enhance reliable ICT infrastructure (communication network)". Because cities are in different development stages, every city encounters distinctive urgent problems related to the next step of urban development. For instance, globally top cities (London and New York) merely interpret the $\mathrm{RC}$ concept in their own ways for urban practice and keep this concept slim in their city plans, while cities in developing countries (Addis Ababa and Surat) made ambitious plans to seize the opportunities for urban development. This means it is an impossible task to build a universal consensus for RC practice.

\subsection{Broader Scope in Encounter with the RC100 Program}

Comparing the two plans on RC, the RC100 plans generally have a wider scope than the city's own RC plans. Figure 1 graphically illustrates and presents the average scores of each cluster in the planning and implementation of five cities and shows the comparison among different cities and within the same city. This shows that the scope of planning has expanded with the intervention of the RC100 program. The only exception is New York, whose RC plan developed immediately after 2012 Hurricane Sandy has a wider scope than its 2015 plan. As the most prosperous and powerful metropolitan in the world, New York does not care for sponsorship from the RC100 program. Although linked to RC100's official website as a key example, "One New York: The Plan for a Strong and Just City" seems like 
a perfunctory submission for the Rockefeller's Foundation since it is the only plan without any indication of its RC100 participation.

(a) London

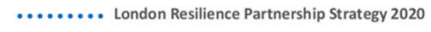

- - - London City Resilience Strategy 2020
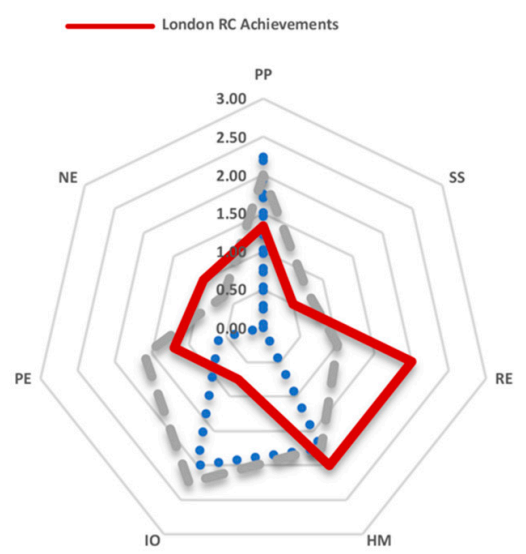

(b) Addis Ababa

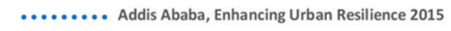

- $-\infty$ Addis Ababa Resilience Strategy 2020

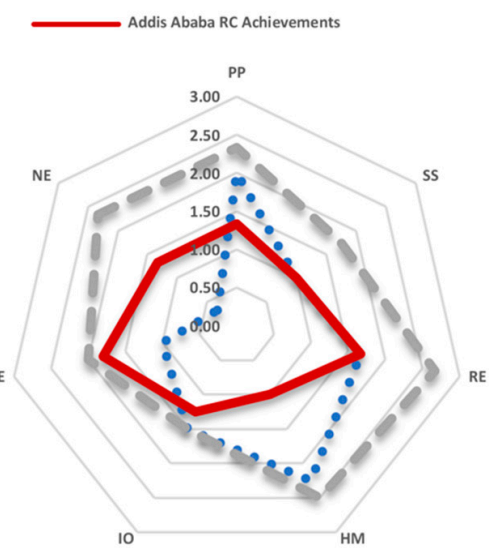

(c) Rotterdam

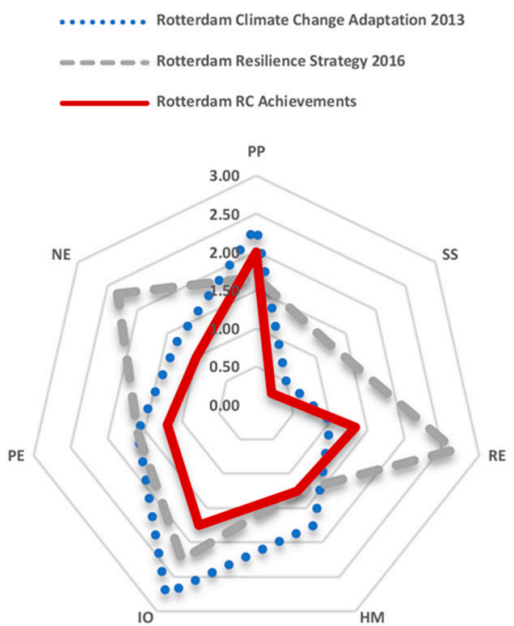

(d) New York

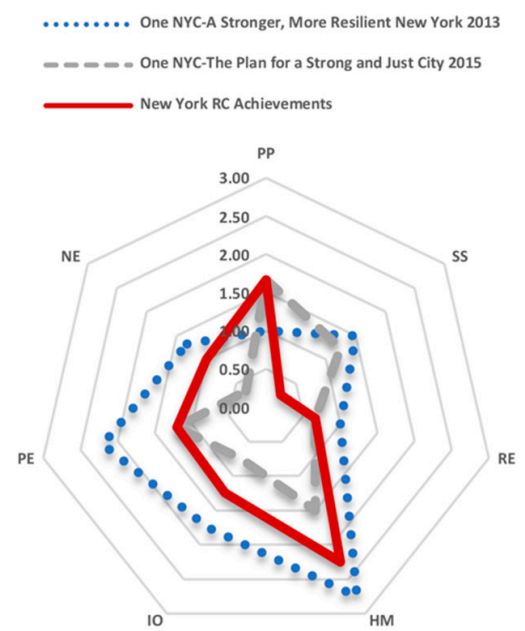

(e) Surat

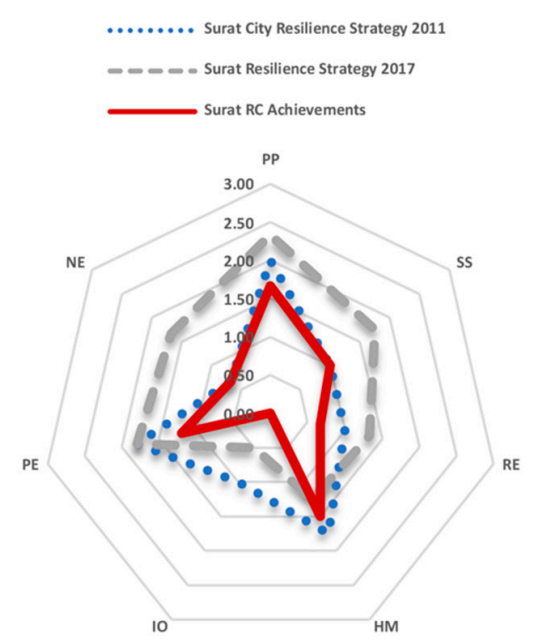

Figure 1. Clusters of focus in five representative cities. (The scores are the average scores for each cluster of each city based on the data in Table 3).

All of the other four RC plans have expanded their scopes, particularly regarding the Robust Economics cluster and the Natural Enhancement cluster (Figure 1). Rotterdam and Addis Ababa included the term resilience in their plans' names years before the RC concept emerged for its water-centered climate change policies and economic re-orientation, respectively $[9,69]$. However, the RC100 program accelerated its original trajectory to a wider coverage [12,70,71]. While Rotterdam's own RC plan in 2013 focused on the analysis of and potential solutions to five typical hazards, its RC 100 plan in 2016 extended to an allencompassing plan that attempted to solve wide social, economic and ecological problems. The most comprehensive plan (highest average score of 2.15)—Addis Ababa Resilience Strategy 2020-puts forward three pillars, 13 goals and 48 actions to build a "thriving, safe, intelligent, green and healthy resilient city" [70]. Similarly, when the RC100 program came to London, both the LRF and Mayor's Office for Policing and Crime (MOPAC) proposed different plans [8]. The MOPAC proposal to tackle cyber-crime and emerging digital threats was selected by political authorities in 2014 [72]. However, the lengthy preparation of London's RC plan has changed its initial narrow goal to a much broader 
scope: traditional disaster mitigation and management have been gradually expanded by a more encompassing vision of climate-change adjustment; MOPAC's cyber-security issues have been expanded to more general social services; and some ideas on flexible planning and design processes and infrastructure maintenance were added. Plans on the encouragement of the RC100 program have become increasingly comprehensive with the ambition to solve more problems.

\subsection{Gap between Planning and Implementation}

The scope of implementation in reality is usually lower than the content of planning in both city-level (Figure 1) and indicators' comparison (Figure 2). Because this assessment only measures the scopes of RC planning and implementation, the real gap in achievements may be even wider. Figure 2 shows that the scope of most indicators is lower in implementation, particularly for two clusters: Social Service and Institutional Optimization (marked with dotted boxes in Figure 2). Three indicators in Social Service-No. 5 "Set ensured human security for providing basic living needs", No. 6 "Assist vulnerable neighborhoods and populations (increase social equity)" and No. 7 "Enhance robust public health systems and emergency medical care"-represent the ideas that are easy to claim but difficult to implement in reality. Although everyone knows that they are important for the whole society and can significantly boost urban resilience, they require a long-term effort with sufficient financial and labor resources. Similarly, for the three points in Institutional Optimization, it is not easy to change the existing planning, design and governance systems within a short period as RC achievements.

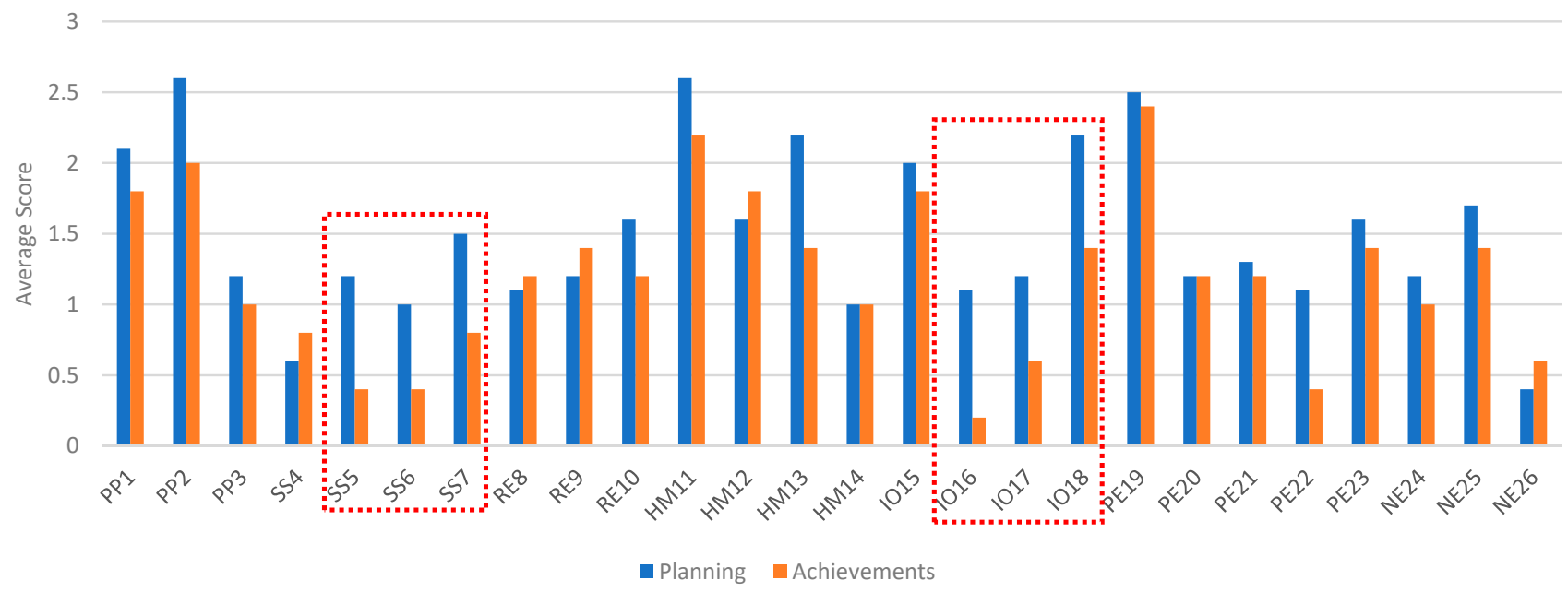

Figure 2. Comparison between the planning and achievements of each indicator. (The average scores are calculated based on the ten RC plans and five cities' achievements for each indicator of the data in Table 3).

Another reason for this gap is that cities prioritize their urgent problems. For instance, both the 2003-2013 structure plan and the 2015 resilient strategy of Addis Ababa allocated a large area of swampy land for flood retention and urban agriculture as an important RC action. However, a so-called "master plan reconciliation" committee of the city administration decided to use the same land for condominium houses. Open areas in the catchment now mainly consist of "residential green space", which implies that they were occupied by informal residents [45]. In the short term, Addis Ababa's housing problem is more urgent than disaster mitigation issues for city authorities. On the one hand, the $\mathrm{RC}$ concept helps cities to identify various uncertain risks that cities may encounter by building a complete evaluation structure to prevent blind spots in urban development; on the other hand, municipal authorities must choose the priority of urban development under such a broad plan when resources are limited. Therefore, as shown in Table 3, the implementation content often corresponds to the more urgent parts of cities' needs. 


\section{Discussion: What RC Brings for Urban Practice?}

The assessment results show that $\mathrm{RC}$, as a changing and expanding concept in academic discourse, may not have as considerable of an impact on innovative urban practice as has been claimed. This section critically reflects on the positive features that RC brings to practice and the constraints that prevent good ideas of RC from translating into the improvement of the built environment.

There is no doubt that the RC concept creates a platform for different stakeholders in cities to communicate regarding topics related to resilience $[8,73]$. In all cases, the journey of making RC plans is a process of building networked governance on strategic mapping of a clear policy and, therefore, setting a clearer agenda with various stakeholders. The forums, workshops and consulting meetings for RC plans are shared platforms to collectively consider the future mode of the built environment in the age of uncertainty. Practitioners benefit from using the RC concept because it empowers the local level to act horizontally against top-down actions. Furthermore, powerful international organizations facilitate intercity sharing for effective and feasible actions on a global scale with financially stimulating initiatives. The RC concept provides a framework for holistically assessing the vulnerability of cities, gaining an opportunity to gather fragmented bureaus and departments to respond to urban challenges together and generating an imaginary knotting point for the future built environment for the general public.

Another noticeable feature of RC is city branding. For many cities, the adoption of RC practice represents a political commitment of city municipalities to post-disaster recovery [50] or is featured in their advertisements for attracting foreign investments and tourists $[73,74]$, regardless of whether the actions have been successfully implemented in reality. The post-Sandy political pressure forced New York to use "resilience" to name its new governance framework, which creatively recalibrated its new and old elements [50]. Ironically, when the most emergency post-storm time passed, New York sought new fashionable labels to substitute the old branding, and RC became a merely specific term for hazard management and flood-related infrastructure (see Supplement S1). Furthermore, for many well-performing cities, RC is a new way to enshrine their advancements among cities and to brand them in a new manner to the general public. For instance, many of Rotterdam's iconic RC achievements (e.g., green roof and water plaza) have been completed or were at least in good progress before the RC concept was introduced to its city plans [24,49]. Similarly, in London, the RC concept has been mainly used for assembling and extolling a number of existing programs instead of bringing new ideas to change the current city planning and development trajectory. Furthermore, RC plans can be an ambitious agenda beyond urban development, such as seeking geopolitical impacts in Addis Ababa. Mayor Diriba Kuma asserted in establishing its RC office [48]: "We want the city to be a model for the region. Addis has already been a leader in promoting climate resilience and green economy and holds a track record of championing resilient initiatives ... " Its Resilient City Office became a propaganda agency to spread the city's achievements that can be linked with RC. Critics argue that the active planning actions in Addis Ababa, including RC plans, represent a propaganda model by the federal government to pursue its geopolitical ambition and influence other countries in the Horn of Africa [75]. Some indicators' wider scopes in implementation compared to planning in Table 1 show that five cities are enthusiastic in advertising some specific resilient-related achievements for city-branding purposes.

However, the shared platform inevitably broadens the scope of the RC concept in practice, as stakeholders tend to input their understanding into RC plans. Furthermore, city branding narratives often ignore the many nuances that $\mathrm{RC}$ research initially aims to achieve and merely focus on the positive image for the general public, regardless of its feasibility and effectiveness [73]. Similar to many concepts in planning, the RC concept has become increasingly vague and broad in practice and can be interpreted and implemented differently for stakeholder needs [76]. More precisely, the five cities started their journey of resilience from a relatively small scope of urgent and local problems such as sudden 
natural disasters or recognized long-term threats (see more details in Supplement S1). New York and Surat responded with their planning actions to the 2012 Hurricane Sandy and the devastating 2006 Surat flood, respectively [50,77]. Rotterdam's location in the low delta area motivates its preparation for climate change, particularly for the sea-level rise [9]. Metropolitan complexity drives London to form the London Resilience Forum (LRF), a network of public and private partners, to prepare for natural hazards and critical infrastructure failure [8]. These motivations have been gradually expanded in the planning stage when more stakeholders were involved and more visions were included, particularly with the intervention of the RC100 program. The meaning and vision of resilience for cities will continue to morph in urban practice, especially as practitioners incorporate their own interpretations and imagination along the way [78]. Although scope expansion itself is not a problem, it amplifies the gap between planning and implementation, as demonstrated in Figure 1.

Therefore, there are concerns that the concept of RC will become an empty signifier in the discourse of the future built environment, as like what happened to "sustainable city", "creative city", and "smart city" [18,79-81]. As Therrien et al. observed in London practice, the "diversity of issues makes it difficult to develop a clear set of interconnected priorities on resilience that reflects a convergence of interests among organizational stakeholders" [8] (p. 7). All claims in the name of RC seem to be an all-winning process, but in many cases, there is an unbalanced consequence that needs to identify winners and losers or those who obtain more privileges in the resilience actions. It would definitely be disappointing if RC is only an umbrella word that merely builds a holistic image of cities and gains wider social support instead of real inspirations for practice. Our assessment results demonstrate that the RC practice actions that are implemented in reality are closely associated with cities' urgent problems rather than how resilient these actions can be for the cities.

\section{Conclusions}

With the help of the scoring evaluation matrix, this study assessed and analyzed five representative cities' practices from planning to implementation. The results demonstrate that the RC concept is usually interpreted with different focuses depending on the city's own needs when it lands on practice. Although cities' initial motivations for resilience were usually narrow, the shared platform that this concept entails and the city branding trend in practice easily triggers plans to expand as comprehensively as possible, particularly with the intervention of the RC100 Program. The holistic solutions that the RC concept aims to offer to cities always encounter difficulties in the implementation process because the limited resources, particularly in the post-2008 austerity governance, mean that cities can only prioritize their urgent issues in their everyday practice.

Therefore, this paper calls for scholars to pay more attention to researching feasible and specific features of RC that can optimize our future built environment. Instead of adding more content or mapping complex networks of a large collection of components in the name of RC, it is more important to elucidate the contribution of specific features to building our urban futures in the grand narrative of RC. In urban practice, regular alignments from planning to implementation are more important in RC practice than proposing one or another unachievable city-branding plan. If the destination of RC is not clear enough, the deleterious dimension of resilience may secretly do the evil rather than bounce back after disturbance, as expected in reality $[15,38]$.

Supplementary Materials: The following is available online at https://www.mdpi.com/article/10 .3390/land10121319/s1, Supplement S1: RC Assessment Raw Data for five representative cities.

Author Contributions: Conceptualization, X.L. and C.W.; methodology, C.W.; software, X.L. and S.L.; validation, C.W.; formal analysis, X.L., S.L. and C.W.; investigation, S.L., X.L. and C.W.; resources, X.L., S.L. and C.W.; data curation, C.W., X.L. and S.L.; writing-original draft preparation, C.W., X.L. and S.L.; writing-review and editing, C.W., X.L. and S.L.; visualization, C.W. and X.L.; supervision, 
C.W.; project administration, C.W.; funding acquisition, C.W. All authors have read and agreed to the published version of the manuscript.

Funding: This research was funded by the Jiangsu Innovation and Entrepreneurship Talent Program, the Future Exploration Program of the School of Architecture, Southeast University and the Student Research Training Program, Southeast University.

Conflicts of Interest: The authors declare no conflict of interest. The funders had no role in the study design; in the collection, analyses, or interpretation of data; in the writing of the manuscript; or in the decision to publish the results. 


\section{Appendix A}

Table A1. Comparison and Summary of Representative RC Assessment Frameworks.

\begin{tabular}{|c|c|c|c|c|c|c|}
\hline Resource & $\begin{array}{l}\text { Urban Hazard Mitigation: } \\
\text { Creating Resilient } \\
\text { Cities [3] }\end{array}$ & $\begin{array}{l}\text { From Fail-Safe to } \\
\text { Safe-to-Fail: Sustainability } \\
\text { and Resilience in the New } \\
\text { Urban World [61] }\end{array}$ & $\begin{array}{l}\text { Planning the Resilient } \\
\text { City: Concepts and } \\
\text { Strategies for Coping with } \\
\text { Climate Change and } \\
\text { Environmental Risk [5] }\end{array}$ & $\begin{array}{l}\text { City Resilience } \\
\text { Framework [62] }\end{array}$ & $\begin{array}{l}\text { Defining the Resilient } \\
\text { City [63] }\end{array}$ & Summary \\
\hline \multirow{3}{*}{ Public Participation } & $\begin{array}{l}\text { Educating developers about } \\
\text { mitigation techniques and } \\
\text { notifying the public }\end{array}$ & & & Education for the public & & $\begin{array}{l}\text { Educate developers and the } \\
\text { public about hazard } \\
\text { mitigation }\end{array}$ \\
\hline & Community's involvement & & & $\begin{array}{l}\text { Community participation } \\
\text { and support; citizen } \\
\text { engagement }\end{array}$ & $\begin{array}{l}\text { Strong civil society and } \\
\text { community networks }\end{array}$ & $\begin{array}{l}\text { Encourage community } \\
\text { involvement and citizen } \\
\text { participation }\end{array}$ \\
\hline & $\begin{array}{l}\text { Facilitate collective learning } \\
\text { and self-organization }\end{array}$ & & & & & $\begin{array}{l}\text { Learn collectively from past } \\
\text { urban hazards }\end{array}$ \\
\hline \multirow{3}{*}{ Social Service } & & & & $\begin{array}{l}\text { Support basic living } \\
\text { standards (safer housing, } \\
\text { energy, drinking water, } \\
\text { sanitation, and food supply) }\end{array}$ & $\begin{array}{l}\text { Ensured human security } \\
\text { (incomes, income equality, } \\
\text { poverty rates, access to } \\
\text { markets and employment, } \\
\text { health and nutrition, etc.) }\end{array}$ & $\begin{array}{l}\text { Set ensured human security } \\
\text { for providing basic living } \\
\text { needs }\end{array}$ \\
\hline & $\begin{array}{l}\text { Adopt recognized equity } \\
\text { standards; assist vulnerable } \\
\text { neighborhoods and } \\
\text { populations }\end{array}$ & & Increase social equity & & & $\begin{array}{c}\text { Assist vulnerable } \\
\text { neighborhoods and } \\
\text { populations (increase social } \\
\text { equity) }\end{array}$ \\
\hline & & & & $\begin{array}{l}\text { Robust public health } \\
\text { systems and sufficient } \\
\text { healthcare and emergency } \\
\text { medical care }\end{array}$ & & $\begin{array}{l}\text { Enhance robust public } \\
\text { health systems and } \\
\text { emergency medical care }\end{array}$ \\
\hline
\end{tabular}


Table A1. Cont.

\begin{tabular}{|c|c|c|c|c|c|c|}
\hline Resource & $\begin{array}{l}\text { Urban Hazard Mitigation: } \\
\text { Creating Resilient } \\
\text { Cities [3] }\end{array}$ & $\begin{array}{c}\text { From Fail-Safe to } \\
\text { Safe-to-Fail: Sustainability } \\
\text { and Resilience in the New } \\
\text { Urban World [61] }\end{array}$ & $\begin{array}{l}\text { Planning the Resilient } \\
\text { City: Concepts and } \\
\text { Strategies for Coping with } \\
\text { Climate Change and } \\
\text { Environmental Risk [5] }\end{array}$ & $\begin{array}{l}\text { City Resilience } \\
\text { Framework [62] }\end{array}$ & $\begin{array}{l}\text { Defining the Resilient } \\
\text { City [63] }\end{array}$ & Summary \\
\hline \multirow{3}{*}{ Robust Economics } & $\begin{array}{l}\text { Mitigate business } \\
\text { interruption impacts }\end{array}$ & $\begin{array}{l}\text { Higher levels of economic } \\
\text { diversity }\end{array}$ & & $\begin{array}{l}\text { Diverse livelihoods and } \\
\text { employment }\end{array}$ & & $\begin{array}{l}\text { Diversify livelihoods that } \\
\text { can mitigate business } \\
\text { interruption impacts }\end{array}$ \\
\hline & & & $\begin{array}{l}\text { Boost ecologically friendly } \\
\text { economy }\end{array}$ & $\begin{array}{l}\text { Sustainable economics with } \\
\text { diversity, integration and } \\
\text { competitiveness }\end{array}$ & & $\begin{array}{c}\text { Adopt sustainable economic } \\
\text { initiatives }\end{array}$ \\
\hline & & & $\begin{array}{l}\text { Applying alternative energy } \\
\text { Policies and actions to } \\
\text { reduce greenhouse gas } \\
\text { emission } \\
\text { Solar panel buildings }\end{array}$ & & & $\begin{array}{l}\text { Use/facilitate alternative } \\
\text { energy (solar, wind, etc. to } \\
\text { reduce greenhouse gas } \\
\text { emission) }\end{array}$ \\
\hline \multirow{4}{*}{ Hazard Management } & $\begin{array}{l}\text { Identifying hazards and } \\
\text { vulnerability, monitor } \\
\text { vulnerability reduction }\end{array}$ & & Vulnerability analysis & $\begin{array}{l}\text { Hazard mapping, } \\
\text { monitoring, assessment, } \\
\text { and warning }\end{array}$ & & $\begin{array}{l}\text { Identify, monitor, and assess } \\
\text { hazards and vulnerability }\end{array}$ \\
\hline & & & & $\begin{array}{l}\text { Effective emergency } \\
\text { response services }\end{array}$ & $\begin{array}{l}\text { Explicit and cross-sectoral } \\
\text { disaster risk reduction } \\
\text { initiatives }\end{array}$ & $\begin{array}{l}\text { Build effective emergency } \\
\text { response } \\
\text { services/initiatives }\end{array}$ \\
\hline & $\begin{array}{l}\text { Strengthening buildings } \\
\text { and public } \\
\text { facilities-flood-proofing } \\
\text { and wind-proofing existing } \\
\text { and new structures through } \\
\text { building codes and } \\
\text { engineering design }\end{array}$ & & & $\begin{array}{l}\text { Appropriate building and } \\
\text { construction codes, } \\
\text { standards and enforcement }\end{array}$ & $\begin{array}{c}\text { Building and/or } \\
\text { construction regulations; } \\
\text { robust built environments } \\
\text { to ensure safety in private } \\
\text { domains }\end{array}$ & $\begin{array}{l}\text { Enhance building hazard } \\
\text { resistance by appropriate } \\
\text { construction regulations }\end{array}$ \\
\hline & $\begin{array}{c}\text { Avoiding hazard } \\
\text { areas—directing new } \\
\text { development away from } \\
\text { hazardous locations and } \\
\text { relocating existing } \\
\text { structures and land uses to } \\
\text { safer areas }\end{array}$ & & $\begin{array}{l}\text { Land use management for } \\
\text { natural hazard prone areas }\end{array}$ & $\begin{array}{l}\text { Appropriate land use and } \\
\text { zoning with a transparent } \\
\text { operation mechanism }\end{array}$ & $\begin{array}{l}\text { Evaluating urban hazards } \\
\text { and likely vulnerabilities to } \\
\text { inform land use and urban } \\
\text { planning }\end{array}$ & $\begin{array}{l}\text { Land use and planning } \\
\text { management for natural } \\
\text { hazard prone areas }\end{array}$ \\
\hline
\end{tabular}


Table A1. Cont.

\begin{tabular}{|c|c|c|c|c|c|c|}
\hline Resource & $\begin{array}{l}\text { Urban Hazard Mitigation: } \\
\text { Creating Resilient } \\
\text { Cities [3] }\end{array}$ & $\begin{array}{l}\text { From Fail-Safe to } \\
\text { Safe-to-Fail: Sustainability } \\
\text { and Resilience in the New } \\
\text { Urban World [61] }\end{array}$ & $\begin{array}{l}\text { Planning the Resilient } \\
\text { City: Concepts and } \\
\text { Strategies for Coping with } \\
\text { Climate Change and } \\
\text { Environmental Risk [5] }\end{array}$ & $\begin{array}{l}\text { City Resilience } \\
\text { Framework [62] }\end{array}$ & $\begin{array}{l}\text { Defining the Resilient } \\
\text { City [63] }\end{array}$ & Summary \\
\hline \multirow{4}{*}{ Institutional Optimization } & $\begin{array}{l}\text { Develop broad hazard } \\
\text { mitigation commitment }\end{array}$ & & & $\begin{array}{l}\text { Wide collaboration with } \\
\text { stakeholders and the public }\end{array}$ & $\begin{array}{l}\text { Increase capacity of local } \\
\text { government institutions }\end{array}$ & $\begin{array}{l}\text { Increase capacity of } \\
\text { governmental institutions } \\
\text { by wide collaboration }\end{array}$ \\
\hline & $\begin{array}{l}\text { Adaptive community } \\
\text { practice }\end{array}$ & $\begin{array}{l}\text { Adaptive planning and } \\
\text { design model with possible } \\
\text { pilot experiments }\end{array}$ & & & & $\begin{array}{c}\text { Adopt a flexible planning } \\
\text { system and adaptive design } \\
\text { process }\end{array}$ \\
\hline & & & $\begin{array}{l}\text { Adaptive governance } \\
\text { management for } \\
\text { uncertainty }\end{array}$ & & & $\begin{array}{c}\text { Employ agile city } \\
\text { management for } \\
\text { uncertainty and challenges }\end{array}$ \\
\hline & & & & $\begin{array}{l}\text { Effective coordination with } \\
\text { other government bodies }\end{array}$ & $\begin{array}{c}\text { Build strong local } \\
\text { government linkages }\end{array}$ & $\begin{array}{l}\text { Effective coordination with } \\
\text { other government bodies }\end{array}$ \\
\hline \multirow{4}{*}{ Physical/Engineering } & $\begin{array}{l}\text { Using structural approaches } \\
\text { such as flood control works, } \\
\text { slope stabilization and } \\
\text { shoreline hardening }\end{array}$ & & & $\begin{array}{c}\text { Robust protective } \\
\text { infrastructure with regular } \\
\text { maintenance }\end{array}$ & $\begin{array}{l}\text { Robust built environments } \\
\text { to ensure safety in private } \\
\text { and public domains }\end{array}$ & $\begin{array}{c}\text { Set robust protective } \\
\text { infrastructure with regular } \\
\text { maintenance }\end{array}$ \\
\hline & $\begin{array}{l}\text { Operate networked } \\
\text { communications }\end{array}$ & & & $\begin{array}{l}\text { Reliable communications } \\
\text { technology and } \\
\text { infrastructure }\end{array}$ & & $\begin{array}{c}\text { Enhance reliable ICT } \\
\text { infrastructure } \\
\text { (communication network) }\end{array}$ \\
\hline & & & $\begin{array}{l}\text { Compact urban form with } \\
\text { high density }\end{array}$ & & & $\begin{array}{l}\text { Optimize sustainable urban } \\
\text { form }\end{array}$ \\
\hline & & $\begin{array}{l}\text { Good pedestrian } \\
\text { transportation }\end{array}$ & Sustainable transport & $\begin{array}{l}\text { Diverse, effective and } \\
\text { affordable transport }\end{array}$ & & $\begin{array}{l}\text { Provide diverse, effective, } \\
\text { affordable, sustainable } \\
\text { transport }\end{array}$ \\
\hline
\end{tabular}


Table A1. Cont.

\begin{tabular}{|c|c|c|c|c|c|c|}
\hline Resource & $\begin{array}{l}\text { Urban Hazard Mitigation: } \\
\text { Creating Resilient } \\
\text { Cities [3] }\end{array}$ & $\begin{array}{l}\text { From Fail-Safe to } \\
\text { Safe-to-Fail: Sustainability } \\
\text { and Resilience in the New } \\
\text { Urban World [61] }\end{array}$ & $\begin{array}{l}\text { Planning the Resilient } \\
\text { City: Concepts and } \\
\text { Strategies for Coping with } \\
\text { Climate Change and } \\
\text { Environmental Risk [5] }\end{array}$ & $\begin{array}{l}\text { City Resilience } \\
\text { Framework [62] }\end{array}$ & $\begin{array}{c}\text { Defining the Resilient } \\
\text { City [63] }\end{array}$ & Summary \\
\hline \multirow{3}{*}{ Natural Enhancement } & $\begin{array}{l}\text { Conserving natural } \\
\text { areas-maintaining and } \\
\text { enhancing the functions of } \\
\text { wetlands, dunes and forests }\end{array}$ & & & $\begin{array}{l}\text { Effectively managed and } \\
\text { protected ecosystems }\end{array}$ & & $\begin{array}{l}\text { Conserve, manage and } \\
\text { protect ecosystems }\end{array}$ \\
\hline & & $\begin{array}{c}\text { Provide sustainable } \\
\text { ecosystem services within } \\
\text { compact cities, blue-green } \\
\text { ecological networks }\end{array}$ & Urban green lands & & & $\begin{array}{l}\text { Optimize urban blue-green } \\
\text { ecological networks within } \\
\text { compact cities }\end{array}$ \\
\hline & & $\begin{array}{l}\text { Maintain diversity in } \\
\text { biological systems }\end{array}$ & & & & $\begin{array}{l}\text { Maintain diversity in } \\
\text { biological systems }\end{array}$ \\
\hline
\end{tabular}




\section{References}

1. Jha, A.K.; Miner, T.W.; Stanton-Geddes, Z. Building Urban Resilience: Principles, Tools, and Practice; World Bank Publications: Washington, DC, USA, 2013.

2. McPhearson, T.; Haase, D.; Kabisch, N.; Gren, Å. Advancing understanding of the complex nature of urban systems. Ecol. Indic. 2016, 70, 566-573. [CrossRef]

3. Godschalk, D.R. Urban hazard mitigation: Creating resilient cities. Nat. Hazards Rev. 2003, 4, 136-143. [CrossRef]

4. Desouza, K.C.; Flanery, T.H. Designing, planning, and managing resilient cities: A conceptual framework. Cities 2013, 35, 89-99. [CrossRef]

5. Jabareen, Y. Planning the resilient city: Concepts and strategies for coping with climate change and environmental risk. Cities 2013, 31, 220-229. [CrossRef]

6. Vale, L.J. The Resilient City: How Modern Cities Recover from Disaster; Oxford University Press: Oxford, UK, 2005.

7. Roberts, D. Prioritizing climate change adaptation and local level resilience in Durban, South Africa. Environ. Urban. 2010, 22, 397-413. [CrossRef]

8. Therrien, M.-C.; Normandin, J.-M.; Paterson, S.; Pelling, M. Mapping and weaving for urban resilience implementation: A tale of two cities. Cities 2021, 108, 102931. [CrossRef]

9. Lu, P.; Stead, D. Understanding the notion of resilience in spatial planning: A case study of Rotterdam, The Netherlands. Cities 2013, 35, 200-212. [CrossRef]

10. Martín, C.; McTarnaghan, S. Institutionalizing Urban Resilience: A Midterm Monitoring and Evaluation Report of 100 Resilient Cities; Urban Institute and The Rockefeller Foundation: New York, NY, USA, 2018.

11. Galderisi, A.; Limongi, G.; Salata, K.-D. Strengths and weaknesses of the 100 Resilient Cities Initiative in Southern Europe: Rome and Athens' experiences. City Territ. Archit. 2020, 7, 16. [CrossRef]

12. Spaans, M.; Waterhout, B. Building up resilience in cities worldwide-Rotterdam as participant in the 100 Resilient Cities Programme. Cities 2017, 61, 109-116. [CrossRef]

13. Roberts, D.; Douwes, J.; Sutherland, C.; Sim, V. Durban's 100 Resilient Cities journey: Governing resilience from within. Environ. Urban. 2020, 32, 547-568. [CrossRef]

14. Vale, L.J. The politics of resilient cities: Whose resilience and whose city? Build. Res. Inf. 2014, 42, 191-201. [CrossRef]

15. Kaika, M. 'Don't call me resilient again!': The New Urban Agenda as immunology ... or ... what happens when communities refuse to be vaccinated with 'smart cities' and indicators. Environ. Urban. 2017, 29, 89-102. [CrossRef]

16. Pizzo, B. Problematizing resilience: Implications for planning theory and practice. Cities 2015, 43, 133-140. [CrossRef]

17. Meerow, S.; Newell, J.P. Urban resilience for whom, what, when, where, and why? Urban Geogr. 2019, 40, 309-329. [CrossRef]

18. De Jong, M.; Joss, S.; Schraven, D.; Zhan, C.; Weijnen, M. Sustainable-smart-resilient-low carbon-eco-knowledge cities; making sense of a multitude of concepts promoting sustainable urbanization. J. Clean. Prod. 2015, 109, 25-38. [CrossRef]

19. Shamsuddin, S. Resilience resistance: The challenges and implications of urban resilience implementation. Cities 2020, 103, 102763. [CrossRef] [PubMed]

20. Sanchez, A.X.; van der Heijden, J.; Osmond, P. The city politics of an urban age: Urban resilience conceptualisations and policies. Palgrave Commun. 2018, 4, 25. [CrossRef]

21. Boano, C. Pathways towards the Resilient City: Presupposition of Equality and Active Justice in Bangkok, Thailand. In Environmental Justice and Urban Resilience in the Global South; Allen, A., Griffin, L., Johnson, C., Eds.; Palgrave Macmillan US: New York, NY, USA, 2017; pp. 137-152.

22. Huck, A.; Monstadt, J.; Driessen, P.P.J.; Rudolph-Cleff, A. Towards Resilient Rotterdam? Key conditions for a networked approach to managing urban infrastructure risks. J. Contingencies Crisis Manag. 2021, 29, 12-22. [CrossRef]

23. Szpakowska-Loranc, E.; Matusik, A. Łódź-Towards a resilient city. Cities 2020, 107, 102936. [CrossRef]

24. Ilgen, S.; Sengers, F.; Wardekker, A. City-To-City Learning for Urban Resilience: The Case of Water Squares in Rotterdam and Mexico City. Water 2019, 11, 983. [CrossRef]

25. DuPuis, E.M.; Greenberg, M. The right to the resilient city: Progressive politics and the green growth machine in New York City. J. Environ. Stud. Sci. 2019, 9, 352-363. [CrossRef]

26. Holling, C.S. Resilience and Stability of Ecological Systems. Annu. Rev. Ecol. Syst. 1973, 4, 1-23. [CrossRef]

27. Holling, C.S.; Gunderson, L.H. Panarchy: Understanding Transformations in Human and Natural Systems; Island Press: Washington, DC, USA, 2002.

28. Adger, W.N. Social and ecological resilience: Are they related? Prog. Hum. Geogr. 2000, 24, 347-364. [CrossRef]

29. Pickett, S.T.; Cadenasso, M.L.; Grove, J.M. Resilient cities: Meaning, models, and metaphor for integrating the ecological, socio-economic, and planning realms. Landsc. Urban Plan. 2004, 69, 369-384. [CrossRef]

30. Ernstson, H.; van der Leeuw, S.E.; Redman, C.L.; Meffert, D.J.; Davis, G.; Alfsen, C.; Elmqvist, T. Urban Transitions: On Urban Resilience and Human-Dominated Ecosystems. AMBIO-A J. Hum. Environ. 2010, 39, 531-545. [CrossRef]

31. Ziervogel, G.; Pelling, M.; Cartwright, A.; Chu, E.; Deshpande, T.; Harris, L.; Hyams, K.; Kaunda, J.; Klaus, B.; Michael, K.; et al. Inserting rights and justice into urban resilience: A focus on everyday risk. Environ. Urban. 2017, 29, 123-138. [CrossRef]

32. Collier, M.J.; Nedović-Budić, Z.; Aerts, J.; Connop, S.; Foley, D.; Foley, K.; Newport, D.; McQuaid, S.; Slaev, A.; Verburg, P.J.C. Transitioning to resilience and sustainability in urban communities. Cities 2013, 32, S21-S28. [CrossRef] 
33. Connolly, J.J.T. From Jacobs to the Just City: A foundation for challenging the green planning orthodoxy. Cities 2019, 91, 64-70. [CrossRef]

34. Ribeiro, P.J.G.; Goncalves, L. Urban resilience: A conceptual framework. Sustain. Cities Soc. 2019, 50, 11. [CrossRef]

35. Webber, S.; Leitner, H.; Sheppard, E. Wheeling out Urban Resilience: Philanthrocapitalism, Marketization, and Local Practice. Ann. Am. Assoc. Geogr. 2021, 111, 343-363. [CrossRef]

36. Leitner, H.; Sheppard, E.; Webber, S.; Colven, E. Globalizing urban resilience. Urban Geogr. 2018, 39, 1276-1284. [CrossRef]

37. Wang, L.; Xue, X.L.; Zhang, Y.X.; Luo, X.W. Exploring the Emerging Evolution Trends of Urban Resilience Research by Scientometric Analysis. Int. J. Environ. Res. Public Health 2018, 16, 29. [CrossRef]

38. Fitzgerald, A. Querying the resilient local authority: The question of 'resilience for whom'? Local Gov. Stud. 2018, 44, 788-806. [CrossRef]

39. Rodrigues, S. Speech to Resilience First. Available online: https://www.dropbox.com/s/ekh3m31moae359m/Speech\%20to\%20 Resilience\%20First\%20by\%20Shirley\%20Rodrigues\%20-\%20120121.pdf?dl=0 (accessed on 2 September 2021).

40. Assefa, M. Urban Resilience in Addis Ketama and Lideta Sub Cities of Addis Ababa: The Case Tekilehaimanot Area Addis Ababa, Ethiopia. Urban Reg. Plan. 2018, 3, 44-54. [CrossRef]

41. Baron, N.; Cherenet, Z. Perceptions and pathways of resilience in Addis Ababa. Int. J. Build. Pathol. Adapt. 2018, 36, 337-353. [CrossRef]

42. Baron, N.; Donath, D. Bridging the Western Gaze-A Research Framework for Spatial Resilience in Addis Ababa. In Proceedings of the Transformation and Resilience in Urban Development. Presented at the 23rd International Seminar on Urban Form, International Seminar on Urban Form, Nanjing, China, 8-10 July 2016.

43. Birhanu, D.; Kim, H.; Jang, C.; Park, S. Flood Risk and Vulnerability of Addis Ababa City Due to Climate Change and Urbanization. Procedia Eng. 2016, 154, 696-702. [CrossRef]

44. Hagos, K.G.; Adnan, M.; Yasar, A.-u.-H. Effect of sidewalk vendors on pedestrian movement characteristics: A microscopic simulation study of Addis Ababa, Ethiopia. Cities 2020, 103, 102769. [CrossRef]

45. Herslund, L.; Backhaus, A.; Fryd, O.; Jørgensen, G.; Jensen, M.B.; Limbumba, T.M.; Liu, L.; Mguni, P.; Mkupasi, M.; Workalemahu, L.; et al. Conditions and opportunities for green infrastructure-Aiming for green, water-resilient cities in Addis Ababa and Dar es Salaam. Landsc. Urban Plan. 2018, 180, 319-327. [CrossRef]

46. Mohamed, A.; Worku, H.; Lika, T. Urban and regional planning approaches for sustainable governance: The case of Addis Ababa and the surrounding area changing landscape. City Environ. Interact. 2020, 8, 100050. [CrossRef]

47. Alem, G. Urban Plans and Conflicting Interests in Sustainable Cross-Boundary Land Governance, the Case of National Urban and Regional Plans in Ethiopia. Sustainability 2021, 13, 3081. [CrossRef]

48. RC100. A Milestone in Addis Ababa's Resilience Journey: A Conversation with Addis Ababa's First Chief Resilience Officer. Available online: https:/ / medium.com/@100ResilientCities/a-milestone-in-addis-ababas-resilience-journey-8c70a8e15e83 (accessed on 15 May 2021).

49. Huck, A.; Monstadt, J.; Driessen, P. Mainstreaming resilience in urban policy making? Insights from Christchurch and Rotterdam. Geoforum 2020, 117, 194-205. [CrossRef]

50. Wakefield, S. Urban resilience as critique: Problematizing infrastructure in post-Sandy New York City. Polit. Geogr. 2020, 79, 102148. [CrossRef]

51. Mahadevia, D.; Bhatia, N.; Verma, P.; Raj, V.; Patel, S. Affordable Housing as Flood Resilient for Low-Income Households: Case of Ahmedabad and Surat. 2018. Available online: https:/ / cept.ac.in/UserFiles/File/CUE/Working\%20Papers/Revised\%20New / CUE\%20WP40\%20-\%20Affordable\%20Housing\%20as\%20Flood\%20Resilient\%20for\%20Low\%20Income\%20Households\%20 Case $\% 20$ of\%20Ahmedabad\%20and\%20Surat $\% 20-\% 20$ Sept $\% 202018 \% 20-\% 20$ RR.pdf (accessed on 12 September 2021).

52. Mavalankar, D. Lessons from Massive Floods of 2006 in Surat City: A Framework for Application of MS/OR Techniques to Improve Dam Management to Prevent Flood. Available online: https:/ /web.iima.ac.in/assets/snippets/workingpaperpdf/2008 -07-06Mavalankar.pdf (accessed on 12 September 2021).

53. Raj, V. Affordable Housing as Flood Resilient for Low Income Households: A Case of Surat. Master's Thesis, CEPT University, Ahmedabad, India, 2018.

54. World Resources Institute India. Implementing the Urban Community Resilience Assessment UCRA in Three Communities in Surat City, 2018. Available online: https://projects.citiesalliance.org/projects/documents/Implementing_the_Urban_ Community_Resilience_Assessment_UCRA_in_Three_Communities_in_Surat_City.pdf (accessed on 17 October 2021).

55. United Nations. 11. Sustainable Cities and Communities. Available online: https://www.globalgoals.org/11-sustainable-citiesand-communities (accessed on 20 November 2021).

56. United Nations Office for Disaster Risk Reduction (UNDRR). Disaster Resilience Scorecard for Cities. 2017. Available online: https:/ / mcr2030.undrr.org/disaster-resilience-scorecard-cities (accessed on 12 November 2021).

57. Cutter, S.L.; Barnes, L.; Berry, M.; Burton, C.; Evans, E.; Tate, E.; Webb, J. A place-based model for understanding community resilience to natural disasters. Glob. Environ. Chang. 2008, 18, 598-606. [CrossRef]

58. Bryant, A.; Charmaz, K. The Sage Handbook of Grounded Theory; Sage: London, UK, 2007.

59. Allen, N.; Davey, M. The Value of Constructivist Grounded Theory for Built Environment Researchers. J. Plan. Educ. Res. 2018, 38, 222-232. [CrossRef] 
60. Ostadtaghizadeh, A.; Ardalan, A.; Paton, D.; Jabbari, H.; Khankeh, H.R. Community disaster resilience: A systematic review on assessment models and tools. PLoS Curr. 2015, 7. [CrossRef] [PubMed]

61. Ahern, J. From fail-safe to safe-to-fail: Sustainability and resilience in the new urban world. Landsc. Urban Plan. 2011, 100, 341-343. [CrossRef]

62. Arup. City Resilience Framework; Arup and Rockefeller Foundation: London, UK, 2014. Available online: https://www rockefellerfoundation.org/wp-content/uploads/City-Resilience-Framework-2015.pdf (accessed on 8 August 2021).

63. Patel, R.; Nosal, L. Defining the Resilient City; United Nations University Centre for Policy Research: New York, NY, USA, 2016.

64. Dey, I. Grounding Categories. In The Sage Handbook of Grounded Theory; Bryant, A., Charmaz, K., Eds.; Sage: London, UK, 2007; pp. 167-190.

65. Oke, C.; Bekessy, S.A.; Frantzeskaki, N.; Bush, J.; Fitzsimons, J.A.; Garrard, G.E.; Grenfell, M.; Harrison, L.; Hartigan, M.; Callow, D.; et al. Cities should respond to the biodiversity extinction crisis. NPJ Urban Sustain. 2021, 1, 11. [CrossRef]

66. Greener City Fund. Available online: https://www.london.gov.uk/what-we-do/environment/parks-green-spaces-andbiodiversity/greener-city-fund (accessed on 9 September 2021).

67. Davenport, S.; Whicheloe, R.; Frith, M.; Massini, P. Urban Greening for Biodiversity Net Gain: A Design Guide. 2021. Available online: https:/ / www.london.gov.uk/sites/default/files/urban_greening_and_bng_design_guide_march_2021.pdf (accessed on 12 October 2021).

68. Koert, M.v.; Brandt, T. Public Transporter RET: Taking a New and Sustainable Route in Rotterdam; RSM Case Development Centre, Erasmus University: Rotterdam, The Netherlands, 2020.

69. World Bank Group; GFDRR. Addis Ababa-Enhancing Urban Resilience: City Strength Resilient Cities Program (English); The World Bank Group: Washington, DC, USA, 2015.

70. RC100. Addis Ababa Resilience Strategy. Available online: https://resilientcitiesnetwork.org/networks/addis-ababa/ (accessed on 15 March 2021).

71. Khader, M. Rotterdam Resilience Strategy, Rotterdam. In Urban Planning for Transitions; Douay, N., Minja, M., Eds.; ISTE: London, UK, 2021; pp. 1-18.

72. London Wins Membership of Prestigious Network of Resilient Cities. Available online: https://www.london.gov.uk/pressreleases/mayoral/london-wins-prestigious-membership (accessed on 8 August 2021).

73. Naef, P. Resilience as a City Brand: The Cases of the Comuna 13 and Moravia in Medellin, Colombia. Sustainability 2020, $12,8469$. [CrossRef]

74. Campelo, A. Global city branding. In A Research Agenda for Place Branding; Medway, D., Warnaby, G., Byrom, J., Eds.; Edward Elgar Publishing: Cheltenham, UK, 2021; pp. 101-116.

75. Lavers, T. Responding to land-based conflict in Ethiopia: The land rights of ethnic minorities under federalism. Afr. Aff. 2018, 117, 462-484. [CrossRef]

76. Wang, C. Do planning concepts matter? A Lacanian interpretation of the urban village in a British context. Plan. Theory 2021 [CrossRef]

77. Rosenzweig, C.; Solecki, W. Hurricane Sandy and adaptation pathways in New York: Lessons from a first-responder city. Glob. Environ. Chang. 2014, 28, 395-408. [CrossRef]

78. Grove, K. Resilience; Routledge: London, UK, 2018.

79. Brown, T. Sustainability as empty signifier: Its rise, fall, and radical potential. Antipode 2016, 48, 115-133. [CrossRef]

80. Khan, S.; Zaman, A.U. Future cities: Conceptualizing the future based on a critical examination of existing notions of cities. Cities 2018, 72, 217-225. [CrossRef]

81. Davidson, M. Sustainability as ideological praxis: The acting out of planning's master-signifier. City 2010, 14, 390-405. [CrossRef] 